\title{
Erkeklerin Hedonik Tüketim Alışkanlıklarının Demografik Değişkenler ve Burçlar Açısından Değerlendirilmesi
}

\author{
Bekir ÖZKANa
}

\section{Özet}

Tüketim çağı olarak adlandırabileceğimiz günümüz dünyasında hedonik tüketim olgusu sıklıkla karşımıza çıkmaktadır. Bireyler, sadece satın alacakları ürün ihtiyacını gidermek için değil, farklı türden ihtiyaçlarını da karşılamak için alışveriş yapmaktadırlar. Bu çalışmanın amacı, erkek tüketicilerin hedonik tüketim eğilimlerinin demografik değişkenler ve burçlar açısından değerlendirilmesidir. Araştırma için farklı illerde yaşayan 18 yaş üzeri 336 erkek ile görüşülmüştür. Araştırmadan elde edilen sonuçlara göre; erkek tüketicilerin en çok hedonik olarak tükettiği ürünler gıda ürünleri iken, en az hedonik olarak tükettikleri ürünler beyaz eşyadır. Ayrıca, erkek tüketicilerin medeni durumlarına, ev ve araba sahibi olup olmamalarına, yaşlarına, bireysel ve aile gelirlerine, eğitim seviyelerine göre hedonik tüketim yapma durumlarında aralarında anlamlı farklılık olduğu tespit edilmiştir. Burçlar açısından değerlendirildiğinde aralarında anlamlı farklılık bulunamamıştır.
Anahtar Kelimeler

Hedonik

Hedonik Tüketim

Erkekler

Demografik

Burçlar

Makale Hakkında

Geliş Tarihi: 29.01.2020

Kabul Tarihi: 12.10 .2020

Doi: $10.18026 /$ cbayarsos.681983

\section{Evaluation Hedonic Consumption Habits of Men in terms of Demographic Variables and Horoscopes}

\begin{abstract}
In today's world that we could name consumption age, we often hear about the concept of hedonic consumption. Individuals shop not only to satisfy the specific product needs that they buy but also to meet a variety of different kinds of needs. The present study's aim is to analyze the hedonic consumption tendencies of male consumers in terms of demographic variables and horoscopes. For the study, 336 men who live in different cities who are older than 18 participated in the study. According to the results, products men consume most hedonically are food products and products men consume least hedonically are white appliances. Also, it is determined that there are significant differences between male consumers in their status on hedonic consumption according to their marital status, whether they own cars and houses or not, their ages, personal and family incomes, and education level. When analyzed as in horoscopes there are no significant differences.
\end{abstract}

Keywords

Hedonic

Hedonic Consumption

Men

Demographic

Horoscopes

About Article

Received: 29.01.2020

Accepted: 12.10 .2020

Doi: 10.18026/cbayarsos.681983

a Assist. Prof. Dr. Bekir ÖZKAN, Bursa Technical University, Faculty of Humanities and Social Sciences, Department of Business Administration, Bursa, Turkey, bekir.ozkan@btu.edu.tr (ORCID ID: 0000-0001-5802-3473) 


\section{Introduction}

Male or female, young or elder, in any condition and location, all individuals consume all their lives and constantly. While consuming, individuals certainly behave differently from one and other. Some of the reasons for this difference are factors such as individuals' gender, income, educational level, their position at their career. In addition to these factors, different styles of consumption are in the literature as well. The present study is based on hedonic consumption and the main purpose of the study is to analyze the hedonic consumption habits of male consumers in terms of different variables.

The first thing that comes to mind when people think of enjoyment is hedonic consumption. Hedonic consumption is a concept that keeps making itself mentioned frequently in our age. It could be stated that hedonic consumption is a weakness consumers show while shopping. In our age, the shopping concept and phenomenon is not seen by individuals as simply an activity to satisfy needs. Shopping can also be considered as a social activity for consumers. Thus, shopping malls are not designed and constructed only to shop but also as places to do different social activities. Therefore, while individuals are shopping to satisfy their needs, they enjoy doing so as well.

We see that there is no gender discrimination in the studies according to consumer behavior literature. But even though this discrimination isn't made, there are studies that are focused only on men (Bakewell ve Mitchell, 2004; Özdemir, 2009) or only on women (Özkan, 2017; Devrani, 2009; Sarıtaş ve Haşıloğlu, 2015; Ibáñez vd., 2011). It could be said that there are more studies focused on women here. The reason for this could be shown as women being keen on shopping more than men and the product items they need are more. So, the concept of shopping is generally considered to be a feminine activity (Miller, 1998; Lunt ve Livingstone, 1992, Oakley, 1976). The fact that there are fewer studies focused on men is one of the main reasons for the present study to be focused only on men. To see if, in the concept of shopping which is mostly endowed to women, the thought that women shop with more hedonic feelings applies for men too, analyzing the hedonic behaviors male consumers show while shopping is thought. Contributing to filling a void in the said literature with a study such as this in especially the hedonic context is aimed.

\section{Hedonic Consumption}

The hedonic concept is described as pleasure and joy. Therefore hedonic consumption phenomenon could be explained as enjoying shopping and consuming. Hirschman and Holbrook (1982: 92) defines hedonic consumption as individuals' behaviors of product usage experiences that are related to their fantasies and emotions. On the basis of hedonic consumption behaviors are reasons such as the joy, excitement, and running away from life's dullness that shopping offers (Carpenter vd., 2005: 45; Erkmen ve Yüksel, 2008: 689). Thus, hedonic consumption could be evaluated as not only the behaviors consumers show while shopping but also the behaviors they show before and after shopping.

The reasons for hedonic shopping can be grouped under six topics. These are adventure shopping, social shopping, gratification shopping, idea shopping, role shopping, and value shopping (Arnold ve Reynolds, 2003: 80-81). 
Adventure shopping: This shopping kind expresses the feeling of being warned, adventures, and being in another world. Shopping with this reason is stated with images of adventure, excitement, enthusiasm, and world of sounds and smells.

Social shopping: On this topic, shopping with friends and family and enjoying doing so and spending time with them is the matter. Socializing while shopping means the opportunity of communication with people. In this case, consumers describe shopping with friends and family as a way to spend time with them. In addition to this, social shopping is associated with human motivation theories that are focused on looking for love and acceptance in interpersonal relationships and becoming coherent, renunciant.

Gratification shopping: Shopping in this sense is described as a way to get rid of stress and negative mood. People who shop for this reason state that they shop to get rid of stress and forget about their problems.

Idea Shopping: shopping in this group is shopping to follow new tendencies and to keep up with fashion, to be informed about new products and developments. A key point for this shopping that men and women express is that they go shopping to keep up with fashion and new tendencies.

Role shopping: This kind of shopping is about the people who are shopping, enjoying shopping for other people. Also, this situation describes the feelings, mood, and the thrill and the joy a people get while looking for a good gift for someone. It is crucial for people to go shopping for their friends and family and it makes people happy.

Value Shopping: In this kind of shopping, the matter is people shopping for discounts, looking for discounts, and bargaining. For this situation, many people stated that bargaining, looking for discounts, and finding low prices is joyful and described shopping as winning a game or overcoming a difficulty.

\section{Male Consumers}

There are specific reasons for studies that are focused only on male consumers. The most significant one of these reasons is men starting to become more important in retail and other consumption environments, and men taking less or no place on studies about consumption (Bakewell ve Mitchell, 2004: 237).

Analyzing gender-based studies, significant differences between men and women are observed. Men tend to consume hedonically less than women (Aydın, 2010: 447; Doğan vd., 2014: 72). When the extents of hedonic consumption are analyzed separately, women are more interested in adventure shopping, social shopping, role shopping, and value shopping than men but there is no significant difference between men and women in gratification shopping and idea shopping (Fettahlıoğlu vd., 2014: 324). In the study done by Kırgiz (2014), the conclusion was that women go gratification shopping more than men. Kruger and Byker (2009) state that women enjoy shopping more than men and see shopping as entertainment. According to a different study, female consumers shop more hedonically, show more brand loyalty, and shop more casually than male consumers (Tifferet ve Herstein, 2012: 179).

The differences between behaviors men and women show while consuming are not only significant on hedonic shopping, but these differences occur in many situations. 
According to Barletta (2003), male consumers do not focus on irrelevant details while shopping, they reduce the shopping criteria and focus on more important points. This approach is based on the benefits of thinking simple. On decisions for shopping for high capacity products, male consumers prefer focusing on the points that they think are the most important. And they tend to make a decision when they find the products that satisfy the most important criteria (as cited in. Özdemir, 2009: 266).

Male consumers have less awareness of outlook and clothing. Also, because of their interpersonal relations being lesser, they tend to provide information to other consumers less. In addition to their impulsive purchasing possibilities, their becoming compulsive customer possibilities are little. But men use information and communication technology devices (cellphones and computers) more than women and they show a deeper interest in these products and brand new technological devices (Mitchell ve Walsh, 2004: 332, 333). Additionally, male consumers shop more impulsively than women in specific product groups. These groups are electronic products, computer software, and music CDs or DVDs (Coley and Burgess, 2003: 292). Aydin (2013), in his study, reached to the conclusion that men give computers more hedonic value than women.

According to Underhill (2000), $72 \%$ of men and $86 \%$ of women check price tags while shopping. As a result of that, men accept higher prices easier than women and they get affected easier. The reason could be described that men saying yes to everything to leave the shop as quickly as possible. In a mall research, the conclusion was that almost all women carry a shopping list but less than one-quarter of men carry a shopping list. Also, men are not able to reject their kids' requests. And mostly men pay while shopping. Because even though men don't enjoy shopping, they enjoy paying for the purchases (as cited in. Özdemir, 2009: 270).

\section{Horoscopes and Consumption}

Horoscopes have certain effects on individuals' personalities, characteristics, and behaviors, and these effects are accepted by some parts of society but aren't accepted by some parts. Even though it can be accepted that horoscopes don't affect our everyday lives, they inevitably affect some of our behaviors, habits, and humor. While the negotiation that if astrology is a science is still on the table, the number of studies focused on horoscopes in marketing increase rapidly.

According to Mitchell and Hagget (1997: 113-131), the usage of astrology in marketing is based on 2 foundations. These are; the effect astrology has on consuming and consumers' psychology. Also, astrology has an effect on the behaviors in the entertainment, smoking, and drinking markets and it is predictable. According to Mitchell and Tate (1998: 249-259), some horoscopes react more to public service ads and tend to buy cigarettes with less tar. Alcohol usage and consumption rates differ depending on age, gender, and horoscopes. Fun based sports differentiate between horoscopes as well.

According to the study Kwak et al. (2000: 94-98) made, generally horoscopes are effective in casual shopping but aren't effective on mandatory shopping. Also, horoscopes aren't effective in product quality evaluation, they are effective in service quality evaluation.

Çakmak and Özkan (2016: 3167), in the study they made, observed that Sagittarius tend to consume vegetables the most, and Scorpio tend to care the least about vegetable consumption. In the same study, the fact that Scorpio are not very environmentally aware comparing to others is concluded. Ozkan et al. (2013: 69-83), in a study that they analyzed if there were any impacts horoscopes have on luxury shopping, had the conclusion that Aquarius, Leo, and 
Libra are most efficient on luxury shopping. According to the same study, the products horoscopes usually consider as most luxurious are white appliances, computers, and cellphones. Uslu Divanoglu and Uslu (2019: 320) observed that Taurus, Leo, Scorpio, and Aquarius give importance to quality and they purchase a product that they think are good without giving it too much of a thought. According to Gulmez et al. (2011: 97) young Aries, Leo, and Sagittarius tend to purchase faster and planless.

In his study, Mitchell (1995: 57) stated that astrology has some interesting opportunities to offer to marketers. And these opportunities are easy to apply because birthdates of consumers are always easy to access. The method of using astrology in marketing like the way of spending spare time, entertainment, clothing and catering. is one of the best methods to reflect personality and lifestyle.

\section{Horoscopes and Their Characteristics}

Horoscopes are thought to have an effect on personality and behaviors from birth till death. Throughout history, horoscopes have been analyzed by many societies and cultures. Originally Turkish Astrology had 36 horoscopes, in today's modern world this number has been lowered to 12. Hence, 3 horoscopes are counted as one in our time. Because the present study is focused only on men, following are the 12 horoscopes and their effects on male consumers.

\section{Aries Man (March 21st- April 20th)}

Aries man are rebellious from birth. They love to stand up to authorities and think they are smarter than everyone else. Aries man don't like to play, and are outspoken. This counts for both career and love life (Goodman, 1989: 30). Mars gives Aries man the courage, recklessness, cuteness, ability to impress, fury, anger, and energy. It's not easy to get along with Aries man. Aries believe in their thoughts and ideas first. (Goodman, 1993: 23). Aries man are also impatient. Aries have the leadership spirit and successful at sports activities.

\section{Taurus Man (April 21st- May 21st)}

Taurus man are extremely patient but don't let anyone tell them what to do. They like shopping and don't act fast on their love life. Taurus man are the manliest of all men. The best Taurus is a father Taurus. Taurus work a lot and need to rest a lot (Goodman, 1989: 66-68). Taurus man are reliable friends, good spouses, caring fathers, and perfect goodmen. Taurus man have specific qualities and habits(Goodman, 1993: 54). Taurus love to eat and so, Taurus man tend to gain weight easily. Taurus are materialistic and wish to save money and have residences and vehicles.

\section{Gemini Man (May 22nd- June 21st)}

If the sun was in Gemini sign when a man was born, this man will not be the same today and tomorrow and will not carry any memories from yesterday. Gemini will change no matter what. The best example for Gemini man having double characters is the confession of a woman who knew a Gemini man (Goodman, 1989: 100-101). Gemini man aren't the kind to settle down. Even if they get married with a sudden decision, they might regret it and try to leave or change in time (Goodman, 1993: 83). Gemini man gets on well with everyone. Conversation, communication, and information are very important to them. 


\section{Cancer Man (June 22nd- July 22nd)}

Cancer man are genuine and impulsive. Even if they change physically, there will be no difference in who they are. Cancer man are not keen on casual clothing, there is seriousness in their clothes (Goodman, 1989: 132-134). It's necessary to be cautious about some behaviors of Cancer man. Cancer man are very emotional (Goodman, 1993: 116). They are very keen on their families, they especially have a strong connection with their mothers. Cancer man can also be selfish from time to time.

\section{Leo Man (July 23rd- August 23rd)}

Almost all Leo man have excellent repairing skills. From a broken doorknob to a spoilt bathroom tap to an electronic device that stopped working, there is nothing that they can't fix. Fixing a Leo man's lost pride is next to impossible (Goodman, 1989: 168-170). Leo man are prideful. Praising and appreciating a Leo man will give good results. They always think they are better (Goodman, 1993: 147). They are generous, kind, and honest to the people they love. They have strong and protective personalities.

\section{Virgo Man (August 24th- September 23rd)}

Virgo man are intelligent. They have a mind as sharp as a steel trap and never forget a special date. Virgo man hate rudeness, vulgarism as much as they hate ignorance, arrogance, and foulness (Goodman, 1989: 198-201). Virgo man are realists. Virgo man can't easily get attached and love someone. They have specific ideas about clothing, manners, etc. They find clothing very important. They don't always wear classy but they always wear clean clothes. They care about intelligence, kindness, elegancy, and courtesy (Goodman, 1993: 178-181). Besides the fact that Virgo man are extremely emotional, they are also meticulous, detail-oriented, ingenious, and perfectionist.

\section{Libra Man (September 24th- October 23rd)}

It's very demanding to ask Libra man to decide on something. Libra man won't be sexually passive until they are 90. It's undeniable that Libra man often tend to give up(Goodman, 1989: 228-230). Libra man have superior characteristics. They have good taste, a soft spot for beauty, care about feelings, and are honest, stable, rightminded, kind, fair, and nice (Goodman, 1993: 208). Libra man are socially developed and good at communication. They are successful as salesmen.

\section{Scorpio Man (October 24th- November 22nd)}

Scorpio man don't accept defeat. They have a temper that could open wounds for life. Scorpio man have pretty high standards, they never choose their friends randomly. Their friends have to match their standards (Goodman, 1989: 267-269). Scorpio can make someone intimate with them or love them both happy or unhappy. Scorpio may or may not have beautiful eyes but they know how to affect people with their eyes. Their looks tell more than their words (Goodman, 1993: 240). Scorpio man are jealous and grudgers. They are good leaders.

\section{Sagittarius Man (November 23rd- December 21st)}

Sagittarius man are very optimistic. They are so optimistic that they never hold grudges. They are superficial in love relationships but are honest about it. They usually are in random relationships and these relationships are so random sometimes that they are in a relationship 
with anyone they see (Goodman, 1989: 304-306). Sagittarius man are cheerful, very active, warm, and positive. They are curious about many things and therefore, they a wide knowledge (Goodman, 1993: 270). Sagittarius man are lucky. They are very honest and clear.

\section{Capricorn Man (December 22nd- January 20th)}

Capricorn man close themselves to other people. They are shy but powerful and courageous. They are nice but ambitious. They are very serious when they are young. They slowly grow into being more active and become the most young-looking and young-behaved people in their groups (Goodman, 1989: 337-339). Capricorn man are self-conscious, shy about their feelings, and have many ambitions. Capricorn man are avid. They always dream of success and getting better in life. They are powerful, hard-working, perseverant, and cautious (Goodman, 1993: 300). They are traditional and deeply connected to their families.

\section{Aquarius Man (January 21st- February 18th)}

Aquarius man spend most of their time to understand other people's feelings but never show their feelings to anyone. They are team members and they tend to work in teams. Aquarius man always ask themselves "What did he/she mean by that?" (Goodman, 1989: 370-371). They are easily liked and loved because they are multi-talented, smart, attractive, and magnificent. They are attracted by many things. They are curious about people the most. Whomever they run into they always want to stop and analyze that person (Goodman, 1993: 330-331). They are successful in science and curious about inventions and discoveries.

\section{Pisces Man (February 19th- March 20th)}

Pisces man can be whatever you want them to be or don't want them to be. Pisces have no biases. They never judge people (Goodman, 1989: 407-409). Pisces man are the most fragile of the 12 horoscopes. They don't like to be compared to others because they are not like anyone else and can get lost in their feelings but they are smart. Pisces man can't decide on something easily. Thus, it takes time for them to take action and they are stargazers (Goodman, 1993: 362363). Pisces man don't easily share their secrets with other people. They have strong feelings.

\section{Methodology}

\section{Purpose and Method of Research}

The purpose of the study is to analyze the male hedonic consumption behaviors in terms of different demographic variables and to specify how often they tend to consume hedonically in what product groups. The data in the current study is collected from October to November in 2017 from men living in 13 cities (İstanbul, Ankara, Kastamonu, Sinop, Karabük, Zonguldak, Karaman, Ordu, Kırşehir, Hatay, Nevşehir, Adıyaman, Samsun). In the study, from non-random sampling methods, convenience sampling method is used. Face to face survey method is used as a data collecting method. The present study is focused on male consumers aged 18 or older. After the useless replies were subtracted, 336 survey forms were analyzed.

The survey is formed in two parts. In the first part, There are questions to specify the hedonic consumption tendencies male consumers have and to analyze how often they shop hedonically in what product groups. The second part's aim is to determine the demographic characteristics of the participants. The questions for specifying hedonic tendencies are formed with the help of a scale developed by Arnold and Reynolds (2003). To determine the levels of 
agreement of male consumers to the statements in the scale, 5 point likert scale (1- Strongly Disagree, 2-Disagree, 3-Undecided, 4-Agree, 5-Strongly Disagree) type questions are asked. To evaluate the frequency of consumers shopping hedonically in any product groups, 5 point likert scale(5-Always, 4-Frequently,3-Sometimes,2-Seldom,1-Never) type questions are used as well.

The collected data in the study is analyzed with SPSS 22. According to the purpose of the study, factor analysis is made to the collected data first. Then, a percentage analysis is made and an independent-sample t-test and Manova are made to test the hypothesizes.

Cronbach Alpha $=0,894$ is found for the hedonic consumption scale used in the study. This result indicates that the scale is credible. Hypothesizes and the findings of the study are given below.

\section{Research Hypothesizes and Model}

Hypothesizes made in the study are as follows.

$\mathrm{H}_{1}$ : There is a significant difference between marital status and the hedonic consumption behaviors of male consumers.

$\mathrm{H}_{2}$ : There is a significant difference between home-ownership status and the hedonic consumption behaviors of male consumers.

$\mathrm{H}_{3}$ : There is a significant difference between car-ownership status and the hedonic consumption behaviors of male consumers.

$\mathrm{H}_{4}$ : There is a significant difference between the ages and the hedonic consumption behaviors of male consumers.

$\mathrm{H}_{5}$ : There is a significant difference between personal incomes and the hedonic consumption behaviors of male consumers.

H6: There is a significant difference between family incomes and the hedonic consumption behaviors of male consumers.

$\mathrm{H}_{7}$ : There is a significant difference between education level and the hedonic consumption behaviors and the hedonic consumption behaviors.

H8: There is a significant difference between horoscopes and the hedonic consumption behaviors of male consumers.

The model of the study is shown in Figure 1. 


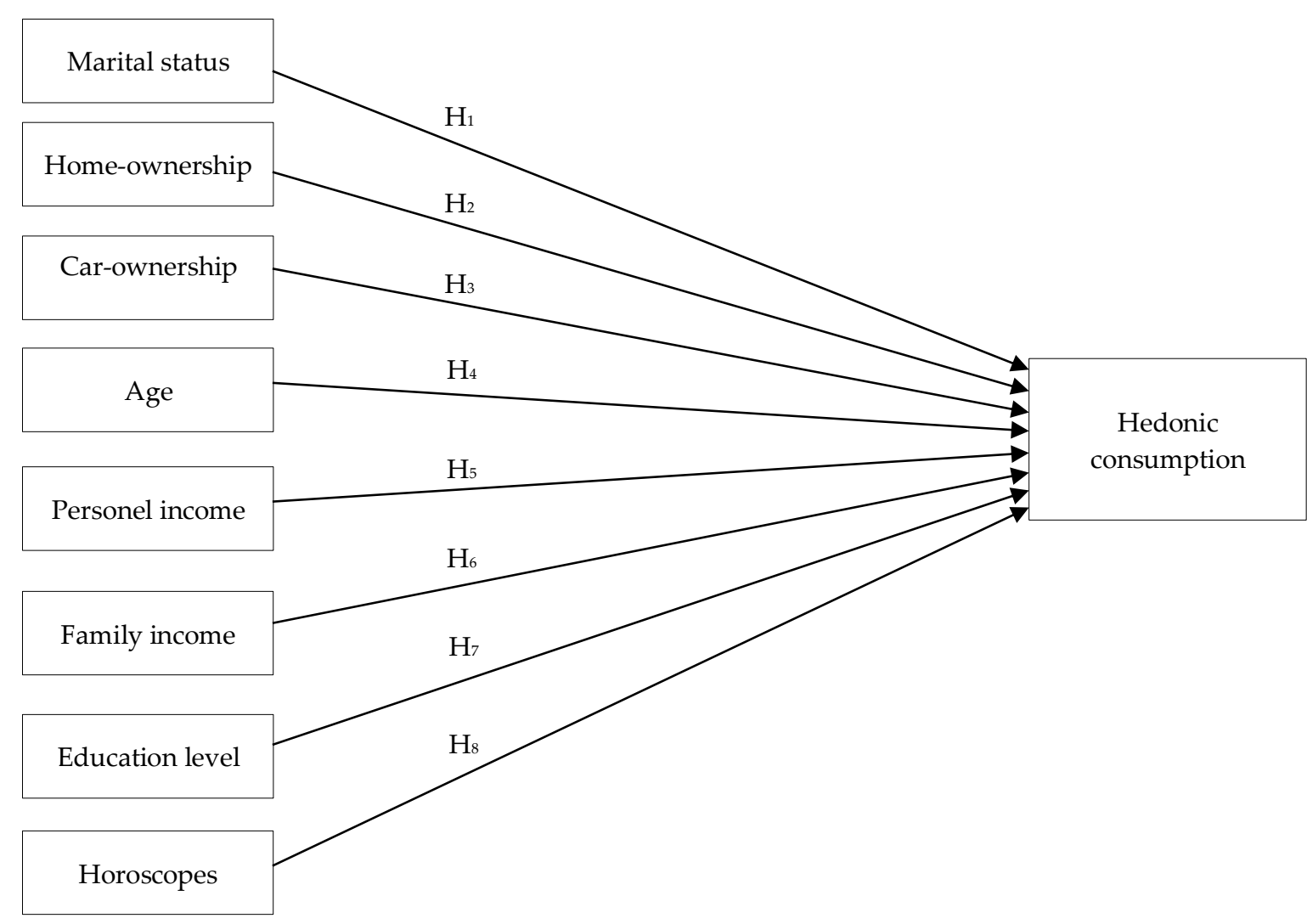

Figure 1. Research model

\section{Research Findings}

The demographic data about the participants are shown in Table 1. According to this data; $\% 60,7$ of men are married and \%39,3 are single. 109 men (32,4\%) are aged 26-35. 118 men have 2001-3000 TL personal income. As family incomes, 149 have 2001-4000 TL. 219 of the participants are homeowners, 117 are tenanted; 214 of them have a car, 122 people don't have a car. Also, 35,4\% (119) of the participants are high school graduates. Lastly, $35(\% 10,4)$ of the participants are Aries, $27(\% 8)$ are Taurus, $30(\% 8,9)$ are Gemini, $20(\% 6)$ are Cancer, $35(\% 10,4)$ are Leo, $35(\% 10,4)$ are Virgo, $34(\% 10,1)$ are Libra, $16(\% 4,8)$ are Scorpio, $20(\% 6,0)$ are Sagittarius, $35(\% 10,4)$ are Capricorn, $26(\% 7,7)$ are Aquarius and $23(\% 6,8)$ are Pisces. 
Table 1. Demographic Characteristics of the Participants

\begin{tabular}{lcclcc}
\hline & Frekans & $\mathbf{\%}$ & & Frekans & \% \\
\hline Age & & & Marital Status & & \\
$18-25$ & 79 & 23,5 & Married & 204 & 60,7 \\
$26-35$ & 109 & 32,4 & Single & 132 & 39,3 \\
$36-45$ & 100 & 29,8 & Income (Individual) & & \\
$46-55$ & 41 & 12,2 & $0-2000$ TL & 112 & 33,3 \\
$56-65$ & 7 & 2,1 & $2001-3000$ TL & 118 & 35,1 \\
Horoscopes & & & $3001-4000$ TL & 51 & 15,2 \\
Aries & 35 & 10,4 & $4001-5000$ TL & 21 & 6,3 \\
Taurus & 27 & 8,0 & $5000+$ TL & 15 & 4,5 \\
Gemini & 30 & 8,9 & Missing & 19 & 5,7 \\
Cancer & 20 & 6,0 & Income (Family) & & \\
Leo & 35 & 10,4 & $0-2000$ TL & 49 & 14,6 \\
Virgo & 35 & 10,4 & 2001-4000 TL & 149 & 44,3 \\
Libra & 34 & 10,1 & $4001-6000$ TL & 83 & 24,7 \\
Scorpio & 16 & 4,8 & 6001-8000 TL & 22 & 6,5 \\
Sagittarius & 20 & 6,0 & $8000+$ TL & 14 & 4,2 \\
Capricorn & 35 & 10,4 & Missing & 19 & 5,7 \\
Aquarius & 26 & 7,7 & Homeownership & & \\
Pisces & 23 & 6,8 & Tenant & 117 & 34,8 \\
Education Status & & & Houseowner & 219 & 65,2 \\
Primary school gra. & 23 & 6,8 & Car Ownership & & \\
High school graduate & 119 & 35,4 & Have & 214 & 63,7 \\
Vocational high school & 44 & 13,1 & Not & 122 & 36,3 \\
graduate & & & & & \\
Bachelor's degree & 133 & 39,6 & & & \\
Master and top gra. & 17 & 5,1 & & & \\
\hline
\end{tabular}

In the factor analysis regarding the hedonic consumption scale used in the study, KMO value was 0,859 (Bartlett; Chi-Square: 3755,096, df: 253, Sig.: 0,000). These results show that the data set is proper for factor analysis. In Table 2, the hedonic consumption average of participants and the factor loads regarding the scale and explained variances regarding each factor and the total of explained variance values are presented. Also, each factor related to Cronbach's Alpha scales is exhibited in Table 2.

According to Table 2, the hedonic consumption style male consumers have the highest average of is role shopping, the hedonic consumption style male consumers have the lowest average is idea shopping. 
Table 2. The Average Hedonic Consumption and Factor Loads

\begin{tabular}{|c|c|c|c|c|c|c|}
\hline & $\mathbf{N}$ & Mean & SD & $\begin{array}{l}\text { Factor } \\
\text { Loads }\end{array}$ & $\begin{array}{l}\text { Explained } \\
\text { Variance }\end{array}$ & $\begin{array}{l}\text { Cronbach's } \\
\text { Alpha }\end{array}$ \\
\hline Adventure Shopping & & 2,5491 & 0,96032 & & \multirow{6}{*}{31,847} & \multirow{6}{*}{0,846} \\
\hline To me, shopping is an adventure & 336 & 2,4137 & 1,21126 & ,751 & & \\
\hline I find shopping stimulating & 336 & 2,7589 & 1,16859 & ,764 & & \\
\hline Shopping is a thrill to me & 336 & 2,5774 & 1,15382 & 798 & & \\
\hline $\begin{array}{l}\text { Shopping makes me feel like I am in my } \\
\text { own universe }\end{array}$ & 336 & 2,4464 & 1,11038 & ,746 & & \\
\hline Value Shopping & & 3,1853 & 0,93885 & & & \\
\hline $\begin{array}{l}\text { For the most part, I go shopping when } \\
\text { there are sales }\end{array}$ & 336 & 3,1845 & 1,18266 & ,735 & \multirow{5}{*}{10,641} & \multirow{5}{*}{0,772} \\
\hline I enjoy looking for discounts when I shop & 336 & 3,2083 & 1,20870 & ,819 & & \\
\hline I enjoy hunting for bargains when I shop & 336 & 3,3214 & 1,29671 & 699 & & \\
\hline I go shopping to take advantage of sales & 336 & 3,0268 & 1,18291 & ,791 & & \\
\hline Role Shopping & & 3,4301 & 0,93179 & & & \\
\hline $\begin{array}{l}\text { I like shopping for others because when } \\
\text { they feel good I feel good }\end{array}$ & 336 & 3,1667 & 1,21024 & ,744 & \multirow{4}{*}{8,065} & \multirow{4}{*}{0,822} \\
\hline $\begin{array}{l}\text { I feel good when I buy things for the } \\
\text { special people in my life }\end{array}$ & 336 & 3,7113 & 1,14474 & ,803 & & \\
\hline $\begin{array}{l}\text { I enjoy shopping for my friends and } \\
\text { family }\end{array}$ & 336 & 3,6577 & 1,07570 & 842 & & \\
\hline $\begin{array}{l}\text { I enjoy shopping around to find the } \\
\text { perfect gift for someone }\end{array}$ & 336 & 3,1845 & 1,18266 & 678 & & \\
\hline Idea Shopping & & 2,5231 & 0,87077 & & \multirow{6}{*}{6,927} & \multirow{6}{*}{0,806} \\
\hline I go shopping to keep up with the trends & 336 & 2,2768 & 1,08347 & 668 & & \\
\hline $\begin{array}{l}\text { I go shopping to keep up with the new } \\
\text { fashions }\end{array}$ & 336 & 2,2887 & 1,13427 & ,769 & & \\
\hline $\begin{array}{l}\text { I go shopping to see what new products } \\
\text { are available }\end{array}$ & 336 & 2,8333 & 1,09363 & ,762 & & \\
\hline I go shopping to experience new things & 336 & 2,6925 & 1,07410 & 703 & & \\
\hline Social Shopping & & 2,7991 & 0,90881 & & & \\
\hline $\begin{array}{l}\text { I go shopping with my friends or family } \\
\text { to socialize }\end{array}$ & 336 & 2,7173 & 1,09564 & ,640 & \multirow{4}{*}{6,410} & \multirow{4}{*}{0,826} \\
\hline $\begin{array}{l}\text { I enjoy socializing with others when I } \\
\text { shop }\end{array}$ & 336 & 2,7054 & 1,10606 & 768 & & \\
\hline $\begin{array}{l}\text { To me, shopping with friends or family is } \\
\text { a social occasion }\end{array}$ & 336 & 2,9435 & 1,13022 & ,783 & & \\
\hline $\begin{array}{l}\text { Shopping with others is a bonding } \\
\text { experience }\end{array}$ & 336 & 2,8304 & 1,15297 & ,768 & & \\
\hline Relaxation Shopping & & 2,5675 & 1,06944 & & \multirow{5}{*}{4,420} & \multirow{5}{*}{0,872} \\
\hline $\begin{array}{l}\text { When I'm in a down mood, I go } \\
\text { shopping to make me feel better }\end{array}$ & 336 & 2,5298 & 1,20905 & ,825 & & \\
\hline To me, shopping is a way to relieve stress & 336 & 2,6429 & 1,21575 & ,778 & & \\
\hline $\begin{array}{l}\text { I go shopping when I want to treat } \\
\text { myself to something special }\end{array}$ & 336 & 2,5298 & 1,16888 & 784 & & \\
\hline Total Variance Explained & & & & 68,310 & & \\
\hline
\end{tabular}


The average of how often male consumers consume hedonically in what product groups is shown in Table 3. According to Table 3, men mostly consume food products hedonically and consume white appliances least hedonically.

Table 3. Rate of Hedonic Consumption in Each Product Line

\begin{tabular}{|c|c|c|c|c|c|c|c|c|c|c|c|}
\hline \multirow{2}{*}{$\begin{array}{l}\text { Product } \\
\text { Group }\end{array}$} & \multicolumn{2}{|c|}{ Always } & \multicolumn{2}{|c|}{ Often } & \multicolumn{2}{|c|}{ Sometimes } & \multicolumn{2}{|c|}{ Rarely } & \multicolumn{2}{|c|}{ Never } & \multirow[t]{2}{*}{ Mean } \\
\hline & $\mathrm{F}$ & $\%$ & $\mathrm{~F}$ & $\%$ & $\mathrm{~F}$ & $\%$ & $\mathrm{~F}$ & $\%$ & $\mathrm{~F}$ & $\%$ & \\
\hline Dress & 80 & 23,8 & 83 & 24,7 & 118 & 35,1 & 44 & 13,1 & 11 & 3,3 & 3,5268 \\
\hline Shoe & 62 & 18,5 & 72 & 21,4 & 140 & 41,7 & 49 & 14,6 & 13 & 3,9 & 3,3601 \\
\hline $\begin{array}{l}\text { Food } \\
\text { Products }\end{array}$ & 133 & 39,6 & 97 & 28,9 & 56 & 16,7 & 34 & 10,1 & 16 & 4,8 & 3,8839 \\
\hline $\begin{array}{l}\text { White } \\
\text { Goods }\end{array}$ & 13 & 3,9 & 6 & 1,8 & 65 & 19,3 & 170 & 50,6 & 82 & 24,4 & 2,1012 \\
\hline $\begin{array}{l}\text { Computer } \\
\text { Personel }\end{array}$ & 28 & 8,3 & 30 & 8,9 & 58 & 17,3 & 146 & 43,5 & 74 & 22 & 2,3810 \\
\hline $\begin{array}{l}\text { Care } \\
\text { Products }\end{array}$ & 60 & 17,9 & 62 & 18,5 & 94 & 28,0 & 69 & 20,5 & 51 & 15,2 & 3,0327 \\
\hline Cellphone & 48 & 14,3 & 36 & 10,7 & 89 & 26,5 & 123 & 36,6 & 40 & 11,9 & 2,7887 \\
\hline Furniture & 15 & 4,5 & 15 & 4,5 & 68 & 20,2 & 151 & 44,9 & 87 & 25,9 & 2,1667 \\
\hline Car & 60 & 17,9 & 43 & 12,8 & 39 & 11,6 & 108 & 32,1 & 86 & 25,6 & 2,6518 \\
\hline
\end{tabular}

An independent $\mathrm{t}$-test is made to determine if there are any significant differences between men's hedonic consumption behaviors in terms of their demographic values. Hedonic consumption behaviors of male consumers according to their marital status, house and car ownership status are shown in Table 4, Table 5, and Table 6.

Table 4. Marital Status Independent T-Test

\begin{tabular}{lcccccccc}
\hline & \multicolumn{2}{c}{ N } & \multicolumn{2}{c}{ Mean } & \multicolumn{2}{c}{ SD } & \multirow{2}{*}{ Sig.(2- } \\
\cline { 2 - 7 } Advanture & Married & Single & Married & Single & Married & Single & & tailed) \\
Value & 204 & 132 & 2,4877 & 2,6439 & 0,95552 & 0,96361 & $-1,459$ & 0,146 \\
Role & 204 & 132 & 3,2047 & 3,1553 & 0,93711 & 0,94431 & 0,470 & 0,639 \\
Idea & 204 & 132 & 3,3468 & 3,5587 & 0,94498 & 0,89946 & $-2,045$ & 0,042 \\
Social & 204 & 132 & 2,4069 & 2,7027 & 0,85271 & 0,87104 & $-3,079$ & 0,002 \\
Relaxation & 204 & 132 & 2,6887 & 2,9697 & 0,92078 & 0,86604 & $-2,796$ & 0,005 \\
\hline
\end{tabular}

According to Table 4 , the conclusion is that there are significant differences between married and single men's behaviors in role shopping $(0,042<0,05)$, idea shopping $(0,002<0,05)$, and social shopping $(0,005<0,05)$. In each hedonic shopping style, the consumption average of single men is higher than married men. The only hedonic shopping type married men have a higher average is value shopping. According to these results, $\mathrm{H}_{1}$ hypothesis is accepted. 
Tablo 5. Homeownership Independent T-Test

\begin{tabular}{|c|c|c|c|c|c|c|c|c|}
\hline & \multicolumn{2}{|c|}{$\mathbf{N}$} & \multicolumn{2}{|c|}{ Mean } & \multicolumn{2}{|c|}{ SD } & \multirow{2}{*}{$t$} & \multirow{2}{*}{$\begin{array}{l}\text { Sig.(2- } \\
\text { tailed) }\end{array}$} \\
\hline & Tenanted & Owner & Tenanted & Owner & Tenanted & Owner & & \\
\hline Advanture & 117 & 219 & 2,6068 & 2,5183 & 1,01620 & 0,93001 & 0,805 & 0,421 \\
\hline Value & 117 & 219 & 3,3269 & 3,1096 & 0,90524 & 0,94970 & 2,031 & 0,043 \\
\hline Role & 117 & 219 & 3,4893 & 3,3984 & 0,90341 & 0,94712 & 0,852 & 0,395 \\
\hline Idea & 117 & 219 & 2,5256 & 2,5217 & 0,89803 & 0,85794 & 0,040 & 0,968 \\
\hline Social & 117 & 219 & 2,9167 & 2,7363 & 0,90972 & 0,90414 & 1,738 & 0,083 \\
\hline Relaxation & 117 & 219 & 2,5926 & 2,5540 & 1,12283 & 1,04218 & 0,314 & 0,753 \\
\hline
\end{tabular}

According to Table 5, homeowners and tenanted men's hedonic consumption behaviors have a significant difference only in value shopping $(0,043<0,05)$. In this case, the average of tenanted men is higher than homeowners $(3,3269>3,1096)$. In all the other hedonic consumption styles, the average consumption of tenanted men is, again, higher than homeowners. According to these results, $\mathrm{H}_{2}$ hypothesis is accepted.

Tablo 6. Car Ownership Independent T-Test

\begin{tabular}{|c|c|c|c|c|c|c|c|c|}
\hline & \multicolumn{2}{|c|}{$\mathbf{N}$} & \multicolumn{2}{|c|}{ Mean } & \multicolumn{2}{|c|}{ SD } & \multirow{2}{*}{$\mathbf{t}$} & \multirow{2}{*}{$\begin{array}{l}\text { Sig.(2- } \\
\text { tailed) }\end{array}$} \\
\hline & Have & Not & Have & Not & Have & Not & & \\
\hline Advanture & 214 & 122 & 2,5129 & 2,6127 & 0,97300 & 0,93823 & $-0,916$ & 0,360 \\
\hline Value & 214 & 122 & 3,0911 & 3,3504 & 0,96499 & 0,87058 & $-2,453$ & 0,015 \\
\hline Role & 214 & 122 & 3,4136 & 3,4590 & 0,95381 & 0,89498 & $-0,430$ & 0,668 \\
\hline Idea & 214 & 122 & 2,5035 & 2,5574 & 0,93963 & 0,73700 & $-0,582$ & 0,561 \\
\hline Social & 214 & 122 & 2,7535 & 2,8791 & 0,94865 & 0,83210 & $-1,219$ & 0,224 \\
\hline Relaxation & 214 & 122 & 2,5125 & 2,6639 & 1,13447 & 0,94134 & $-1,315$ & 0,190 \\
\hline
\end{tabular}

According to Table 6, the only significant difference between men who own cars and men who don't is in value shopping $(0,015<0,05)$. The average of men that don't have cars is higher than men who have cars. $(3,3504>3,0911)$. In other hedonic consumption styles, the average consumption of men that don't have cars is higher than men who have cars as well. According to these results, $\mathrm{H}_{3}$ hypothesis is accepted.

Table 7. Age Manova Analysis

\begin{tabular}{lccccccc}
\hline \multicolumn{7}{c}{ Averages } \\
\hline Advanture & $\mathbf{1 8 - 2 5}$ & $\mathbf{2 6 - 3 5}$ & $\mathbf{3 6 - 4 5}$ & $\mathbf{4 6 - 5 5}$ & $\mathbf{5 6 - 6 5}$ & $\mathbf{F}$ & Sig \\
Value & 2,614 & 2,667 & 2,473 & 2,335 & 2,321 & 1,273 & 0,280 \\
Role & 3,212 & 3,211 & 3,175 & 3,128 & 2,964 & 0,173 & 0,952 \\
Idea & 3,611 & 3,433 & 3,410 & 3,165 & 3,179 & 1,729 & 0,143 \\
Social & 2,696 & 2,573 & 2,462 & 2,201 & 2,536 & 2,434 & 0,047 \\
Relaxation & 2,997 & 2,883 & 2,605 & 2,756 & 2,286 & 2,957 & 0,020 \\
\hline
\end{tabular}

According to Table 7, when the age groups are analyzed there are significant differences in idea shopping $(0,047<0,05)$ and social shopping $(0,020<0,05)$. Tukey test from PostHoc tests is made to identify the source of differences. According to the results of Tukey test, the difference in idea shopping is between ages 18-25 (avg.2,696) and 46-55 (avg. 2,201), (Sig. 0,026). The 
difference in social shopping is between ages 18-25 (avg. 2,996) and 36-45 (avg. 2,605), (Sig. $0,033)$. According to these results, $\mathrm{H}_{4}$ hypothesis is accepted.

Table 8. Income (Personal) Manova Analysis

\begin{tabular}{lccccccc}
\hline \multicolumn{7}{c}{ Averages } \\
\hline & $\mathbf{0 - 2 0 0 0}$ TRY & $\mathbf{2 0 0 1 - 3 0 0 0}$ & $\mathbf{3 0 0 1 - 4 0 0 0}$ & $\mathbf{4 0 0 1 - 5 0 0 0}$ & $\mathbf{5 0 0 0 +}$ TRY & F & Sig \\
Advanture & 2,5045 & 2,5318 & TRY & TRY & & & \\
Value & 3,2277 & 3,2839 & 3,2255 & 2,2500 & 2,8833 & 1,040 & 0,387 \\
Role & 3,3683 & 3,4195 & 3,5049 & 3,0833 & 2,6833 & 1,924 & 0,106 \\
Idea & 2,5826 & 2,5381 & 2,3431 & 2,1190 & 2,9000 & 1,874 & 0,115 \\
Social & 2,7969 & 2,7331 & 2,8873 & 2,5833 & 2,9667 & 2,830 & 0,025 \\
Relaxation & 2,6190 & 2,4492 & 2,6340 & 2,3492 & 2,7333 & 0,732 & 0,612 \\
& & & & & & & 0,566 \\
\hline
\end{tabular}

According to Table 8, when personal incomes are considered, there is a significant difference only in idea shopping $(0,025<0,05)$. Tukey test from PostHoc tests is made to identify the source of differences. According to the results of the Tukey test, the difference is caused by the incomes 4001-5000 TRY (avg. 2,1190) and 5000+ TRY (avg. 2,9667), (Sig. 0,032). According to these results, $\mathrm{H}_{5}$ hypothesis is accepted.

Table 9. Income (Family) Manova Analysis

\begin{tabular}{lccccccc}
\hline \multicolumn{7}{c}{ Averages } \\
\hline & $\mathbf{0 - 2 0 0 0}$ TRY & $\mathbf{2 0 0 1 - 4 0 0 0}$ & $\mathbf{4 0 0 1 - 6 0 0 0}$ & $\mathbf{6 0 0 1 - 8 0 0 0}$ & $\mathbf{8 0 0 0 +}$ TRY & F & Sig \\
Advanture & 2,4541 & 2,5151 & TRY & TRY & & & \\
Value & 3,0765 & 3,3624 & 3,0693 & 2,4205 & 3,1250 & 1,499 & 0,202 \\
Role & 3,2449 & 3,4312 & 3,5030 & 3,4432 & 3,489 & 3,999 & 0,004 \\
Idea & 2,6327 & 2,5520 & 2,2831 & 2,5114 & 3,0893 & 3,668 & 0,615 \\
Social & 2,7653 & 2,7651 & 2,7500 & 3,0909 & 2,7143 & 0,700 & 0,010 \\
Relaxation & 2,4898 & 2,5660 & 2,4297 & 2,7121 & 2,9524 & 0,917 & 0,454 \\
\hline
\end{tabular}

When the family incomes are considered, as can be seen in Table 9, there are significant differences in value shopping and idea shopping. Tukey test from PostHoc tests is made to identify the source of differences. According to the results of Tukey test, the difference in value shopping is because of the incomes 2001-4000 TRY (avg. 3,3624) and 8000+ TRY (avg. 2,4821), (Sig. 0,007). The difference in idea shopping is because of the incomes 4001-6000 TRY (avg. 2,2831) and 8000+ TRY (avg. 3,0893), (Sig. 0,011). According to these results, H6 hypothesis is accepted. 
Table 10. Level of Education Manova Analysis

\begin{tabular}{lccccccc}
\hline \multicolumn{7}{c}{ Averages } \\
& $\begin{array}{c}\text { Primary } \\
\text { School } \\
\text { Graduate }\end{array}$ & $\begin{array}{c}\text { High } \\
\text { School } \\
\text { Graduate }\end{array}$ & $\begin{array}{c}\text { Vocational } \\
\text { High Sch. } \\
\text { Graduate }\end{array}$ & $\begin{array}{c}\text { Bachelor's } \\
\text { Degree }\end{array}$ & $\begin{array}{c}\text { Postgraduate } \\
\text { Degree }\end{array}$ & F & Sig. \\
Advanture & 1,9239 & 2,5798 & 2,6818 & 2,5620 & 2,7353 & 2,908 & 0,022 \\
Value & 3,5326 & 3,1239 & 3,2955 & 3,1429 & 3,1912 & 1,135 & 0,340 \\
Role & 3,0978 & 3,4097 & 3,5000 & 3,4643 & 3,5735 & 0,952 & 0,434 \\
Idea & 2,1522 & 2,6870 & 2,4318 & 2,4361 & 2,7941 & 3,034 & 0,018 \\
Social & 2,6196 & 2,7332 & 3,0057 & 2,7932 & 3,0147 & 1,193 & 0,314 \\
Relaxation & 2,1159 & 2,6190 & 2,7500 & 2,4987 & 2,8824 & 1,942 & 0,103 \\
\hline
\end{tabular}

According to Table 10, when hedonic consumption behaviors are analyzed in terms of the level of education, there are differences in adventure shopping and idea shopping. Tukey test from PostHoc tests is made to identify the source of differences. According to the results of the Tukey test, the differences in adventure shopping are between primary school graduates (avg. 1,9239) and high school graduates (avg. 2,5798) (Sig. 0,022) and between primary school graduates (avg. 1,9239) and vocational high school graduates (avg. 2,6818) (Sig. 0,018) and between primary school graduates (avg. 1,9239) and bachelors (avg. 2,5620) (Sig. 0,026). The source of the difference in idea shopping couldn't be identified with the Tukey test. Gabriel test from PostHoc tests is made. According to the results of Gabriel test, the source of the difference in idea shopping is between primary school graduates (avg. 2,1522) and high school graduates (avg. 2,6870) (Sig. 0,036). According to these results, $\mathrm{H}_{7}$ hypothesis is accepted.

Table 11. Horoscopes Manova Analysis

\begin{tabular}{|c|c|c|c|c|c|c|c|c|c|c|c|c|c|c|}
\hline \multicolumn{15}{|c|}{ Averages } \\
\hline $\mathbf{N}$ & $\begin{array}{c}\text { Ari. } \\
35\end{array}$ & $\begin{array}{c}\text { Tau. } \\
27\end{array}$ & $\begin{array}{c}\text { Gem. } \\
30\end{array}$ & $\begin{array}{c}\text { Can. } \\
20\end{array}$ & $\begin{array}{c}\text { Leo } \\
35\end{array}$ & $\begin{array}{c}\text { Vir. } \\
35\end{array}$ & $\begin{array}{c}\text { Lib. } \\
34\end{array}$ & $\begin{array}{c}\text { Sco. } \\
16\end{array}$ & $\begin{array}{c}\text { Sag. } \\
20\end{array}$ & $\begin{array}{c}\text { Cap. } \\
35\end{array}$ & $\begin{array}{c}\text { Aqu. } \\
26\end{array}$ & $\begin{array}{c}\text { Pis. } \\
23\end{array}$ & $\mathbf{F}$ & Sig. \\
\hline Advanture & 2,950 & 2,444 & 2,317 & 2,575 & 2,521 & 2,550 & 2,699 & 2,547 & 2,313 & 2,529 & 2,481 & 2,478 & 0,956 & 0,487 \\
\hline Value & 2,886 & 3,194 & 3,317 & 3,000 & 3,064 & 3,200 & 3,265 & 3,297 & 3,375 & 3,329 & 2,904 & 3,522 & 1,181 & 0,299 \\
\hline Role & 3,764 & 3,574 & 3,483 & 3,375 & 3,207 & 3,429 & 3,294 & 3,531 & 3,488 & 3,307 & 3,288 & 3,500 & 0,873 & 0,567 \\
\hline Idea & 2,686 & 2,491 & 2,583 & 2,275 & 2,514 & 2,486 & 2,610 & 2,625 & 2,438 & 2,521 & 2,510 & 2,413 & 0,376 & 0,965 \\
\hline Social & 2,936 & 2,713 & 2,975 & 2,725 & 2,593 & 2,664 & 2,904 & 2,906 & 2,788 & 2,936 & 2,606 & 2,837 & 0,679 & 0,758 \\
\hline Relaxation & 2,895 & 2,605 & 2,589 & 2,533 & 2,371 & 2,390 & 2,775 & 2,604 & 2,483 & 2,476 & 2,769 & 2,246 & 0,921 & 0,520 \\
\hline
\end{tabular}

When the horoscopes of the consumers are analyzed; according to Table 11, it is seen that there are no significant differences between horoscopes in terms of the six factors. According to these results, $\mathrm{H}_{8}$ hypothesis is rejected.

\section{Discussion and Conclusion}

In the study made to identify the hedonic consumption tendencies of male consumers, factor analysis is made to the used scale. As the result of the factor analysis, 6 extents are determined and this result is the same as the result of the study made by Arnold and Reynolds (2003).

The concept that people don't only shop reasonably but also shop for pleasure, joy, and see shopping as a social activity has become an unchanging fact of our world. Shopping for pleasure, instead of shopping reasonably, can be accepted as hedonic shopping. The aim of 
the present study is to analyze the hedonic consumption reasons of male consumers in terms of the demographic variables and determine if horoscopes have any impact on the situation.

According to the study's results; male consumers tend to consume food products hedonically. In a study, the conclusion was that from food products, products like chocolate, confectionery, and potato chips are consumed only hedonically (Crowley vd., 1992: 246). Çakmak and Çakır (2012), in a study they made, concluded that the product groups consumers preferred the most for hedonic consumption purposes are, in order, clothing, food, and electronic appliances, respectively. According to Alba and Williams (2013), electronic devices such as cellphones and computers help satisfy not only hedonic purposes but also pragmatic purposes. Hedonic products such as food can be consumed in different emotion levels by consumers. According to another study, the most preferred product groups are, in order, clothing, food, and personal care products (Ünal ve Ceylan, 2008: 175). In that study, the product group that the consumers consumed least hedonically are white appliances. This is thought to be caused by white appliances being mostly identified with women.

When male consumers' marital statuses are analyzed, single men's average of hedonic consumption is higher than married men's. Generally analyzed, it is seen that single men tend to shop more hedonically than married men (Doğan vd., 2014: 76). Especially in role shopping, idea shopping, and social shopping; there are significant differences between single men and married men.

When we analyzed the subject as to whether the consumers had cars or houses; between homeowners and consumers that don't own homes, the only difference is in value shopping; between car owners and consumers that don't own cars, the only difference is in value shopping. In both cases, consumers that don't own cars or homes value shop more than consumers that own cars or homes. This can be explained with people's incomes. People who have lower incomes tend to care more about value shopping.

When male consumers are analyzed in terms of their age ranges, consumers had significant differences in idea shopping and social shopping. According to the results, men who are aged 18-25 have higher averages in idea shopping and social shopping than middle-aged men. This could be an indicator that young men shop to get ideas and to socialize more. Aytekin and Ay (2015), in the study they made, concluded that consumers aged 18-25 shop more hedonically than other age groups. Tifferet and Herstein (2012), in the study they made, state that younger consumers tend to shop more impulsively.

When consumers' incomes were analyzed; in personal income division, there is a difference between incomes only in idea shopping. Consumers that have 4001-5000 TL income have a lower average in idea shopping than consumers that have over 5000 TL income. According to this result, consumers with higher incomes tend to shop to get ideas more. Generally, as the income increases the amount of hedonic shopping gets higher (Açıalın and Yaşar, 2017: 582). In another study, any relation between higher or lower incomes and hedonic consumption tendencies couldn't be identified (Özkan vd. 2017: 2346).

In family income, there are significant differences between consumers in idea shopping and value shopping. In value shopping, as the family income gets higher the amount of value shopping gets lower. This result shows that families with lower incomes care more about prices. In idea shopping, families with higher incomes shop to get ideas more than families with lower incomes. According to the study Çakmak and Çakır (2012) made, the amount of 
hedonic shopping gets higher as the family income gets higher. In addition to this, as the family income gets higher, the tendency to shop more impulsively increases (Tifferet ve Herstein, 2012: 179).

When their educational levels are analyzed, male consumers have significant differences in adventure shopping and idea shopping. In adventure shopping, the conclusion was that with higher education levels the average gets higher.

As in horoscopes, there are no significant differences in terms of the 6 factors. But Aries have the highest average in adventure, role, idea, and gratification shopping, Pisces have the highest average in value shopping, and Gemini have the highest average in social shopping.

\section{Limitations and Future Research}

This study is made focusing only on male consumers. Because of time and budget restrictions, convenience sampling method is preferred and the sample size is restricted with 13 cities. The fact that the number of people who are reached for this study being limited, because of the same restrictions, can indicate weaknesses in terms of the analyses made being the definite result. Thus, this situation prevents generalizing the study results. The participants belonging to certain cultures and being affected by the regions' and the cities' cultures prevent the results from being valid for all society. Another important restriction of the study is the incompetence of other studies made in this subject. The incompetence of the studies in this subject, especially those that are focused on men, is a problem for giving the necessary literature information.

Making the study in more and different cities, people who have different socio-cultural characteristics participating will help to generalize the results. In the same way, the number of participants being more will increase the credibility of the results. Different results can be achieved by using different factor analysis methods on the collected data. In addition to this, analyzing the hedonic consumption phenomenon in terms of, in addition to demographic characteristics, personality characteristics, different consumption characteristics, different behavior characteristics will help to reach a variety of results.

\section{References}

Açıkalın, S. \& Yaşar, M. (2017). Hedonik ve faydacı tüketim bağlamında tüketici davranışlarının incelenmesi: gençlerin hedonik tüketim eğilimlerini belirlemeye yönelik bir araştırma [A research on investigation of the consumer behaviors in the context of hedonic and utilitarian consumption: Determining the hedonic consumption tendency of youth]. The Journal of International Social Research, 10(48), 570-585.

Alba, J. W., \& Williams, E. F. (2013). Pleasure principles: A review of research on hedonic consumption. Journal of Consumer Psychology, 23(1), 2-18.

Arnold, M. J., \& Reynolds, K. E. (2003). Hedonic shopping motivations. Journal of Retailing, 79, 77-95.

Aydın, S. (2010). Hedonik alışverişin cinsiyet, gelir ve yerleşim büyüklüğüne göre farklılaşması üzerine bir araştırma [A study on differentiation of hedonic shopping in respect of gender, income and size of settlement]. Süleyman Demirel University The Journal of Faculty of Economics and Administrative Sciences, 15(3), 435-452. 
Aytekin, P. \& Ay, C. (2015). Hedonik tüketim ve anlık satın alma ilişkisi [The relationship between hedonic consumption and impulse buying]. Academic Review of Economics and Administrative Sciences, 8(1), 141-156.

Bakewell, C., \& Mitchell, V. W. (2004). Male consumer decision-making styles. The International Review of Retail, Distribution and Consumer Research, 14(2), 223-240.

Carpenter, J. M., Moore, M., \& Fairhurst, A. E. (2005). Consumer shopping value for retail brands. Journal of Fashion Marketing and Management: An International Journal, 9(1), 43-53.

Coley, A., \& Burgess, B. (2003). Gender differences in cognitive and affective impulse buying. Journal of Fashion Marketing and Management, 7(3), 282-295.

Crowley, A. E., Spangenberg, E. R., \& Hughes, K. R. (1992). Measuring the hedonic and utilitarian dimensions of attitudes toward product categories. Marketing Letters, 3(3), 239249.

Çakmak, A. Ç., \& Özkan, B. (2016). Üniversite öğrencilerinin ekolojik farkındalıkları ile yeşil tüketim alışkanlıklarının farklı değişkenler perspektifinden karşılaştırılması: interaktif bir uygulama [Comparison of ecological awareness and green consumption habits of university students by different variable perspective: An interactive application]. Journal of the Human and Social Science Researches, 5(8), 3144-3170.

Çakmak, A. Ç., \& Çakır, M. (2012). 12-18 yaş arası gençlerin hedonik tüketim davranışlarının incelenmesi: Kocaeli şehir merkezinde bir araştırma [Analysis of hedonic consumption behaviors of the young people aged 12-18: A research in the city center of Kocaeli]. Journal of History Culture and Art Research, 1(4), 171-189.

Devrani, T. K. (2009). Marka sadakati öncülleri: Çalışan kadınların kozmetik ürün tüketimi üzerine bir çalışma [The antecedents of customer loyalty: A study in women employees consumption of the cosmetic products]. Suleyman Demirel University The Journal of Faculty of Economics and Administrative Sciences, 14(3), pp.407-421.

Doğan, H. G., Gürler, A. Z., \& A ğcadağ, D. (2014). Hedonik tüketim alışkanlıkları üzerine etkili faktörlerin değerlendirilmesi (Tokat ili örneği) [Evaluation of effective factor to hedonic consumption habits (Tokat province case)]. Journal of International Social Research, 7(30), 6977 .

Erkmen, T., \& Yüksel, C. A. (2008). Tüketicilerin alışveriş davranış biçimleri ile demografik ve sosyo kültürel özelliklerinin incelenmesine yönelik bir araştırma [A study about consumers' buying behavior patterns and their demographic and socio-cultural characteristics]. Ege Academic Review, 8(2), 683-727.

Fettahlığlu, H. S., Yıldız, A., \& Birin, C. (2014). Hedonik tüketim davranışları: Kahramanmaraş Sütçü İmam Üniversitesi ve Adryaman Üniversitesi öğrencilerinin hedonik alışveriş davranışlarında demografik faktörlerin etkisinin karşılaştırmalı olarak analizi [Hedonic comsumption behaviors: A comparative analysis of the effects of demographic factors on hedonic shopping behaviors of the students at Kahramanmaraş Sütçü İmam University and Adıyaman University]. The Journal of Academic Social Science Studies, 27, 307-331. 
Goodman, L. (1989). Burçlar. (Çev. Sevim Or). İstanbul: Star, Yaprak Yayıncılık-Dağıtımcllık Goodman, L. (1993). Burçlar ve Yıldızlar. (Çev. Gülten Suveren). İstanbul: Sümer Kitabevi

Gülmez, M., Kitapçı, O., \& Dörtyol, İ. T. (2011). The effect of astrology on young customer behaviors. Studies in Business and Economics, 6(3), 97-109.

Hirschman, E. C.,\& Holbrook, M. B. (1982). Hedonic consumption: Emerging concepts, methods and propositions. Journal of Marketing, 46(3), 92-101.

Ibáñez, V. A., Hartmann, P., Diehl, S., \& Terlutter, R. (2011). Women satisfaction with cosmetic brands: The role of dissatisfaction and hedonic brand benefits. African Journal of Business Management, Vol. 5(3), 792-802.

Kirgiz, A. (2014). Hedonism, a consumer disease of the modern age: gender and hedonic shopping in Turkey. Global Media Journal, 4(8), 200-212.

Kruger, D., \& Byker, D. (2009). Evolved foraging psychology underlies sex differences in shoping experiences and behaviors. Journal of Social, Evolutionary, and Cultural Psychology, $3(4), 328$.

Kwak, H., Jaju, A., \& Zinkhan, G. M. (2008). Astrology: Its influence on consumers' buying patterns and consumers' evaluations of products and services. Developments In Marketing Science, 23, 94-98.

Lunt, P. K., \& Livingstone, S. (1992). Mass consumption and personal identity: Everyday economic experience. Open University Press.

Miller, D. (1998). A theory of shopping. Cornell University Press.

Mitchell, V-W. (1995). Using astrology in market segmentation. Management Decision, 33(1), 4857.

Mitchell, V-W., \& Haggett, S. (1997). Sun-Sign astrology in market segmentation: An empirical investigation. Journal of Consumer Marketing, 14(2), 113-131.

Mitchell, V-W., \& Tate, E. (1998). Do consumers' star signs influence what they buy? Marketing Intelligence \& Planning, 16(4), 249-259.

Mitchell, V. W., \& Walsh, G. (2004). Gender differences in German consumer decision-making styles. Journal of Consumer Behaviour: An International Research Review, 3(4), 331-346.

Oakley, A. (1974). Housewife. Lane, Allen.

Özdemir, E. (2009). Cinsiyet bazlı farklılıklar ve erkek tüketicilere yönelik pazarlama stratejileri [Gender-based differences and marketing strategies to male consumers]. Electronic Journal of Social Sciences, 8(29), 259-281.

Özkan, B. (2017). Hedonik tüketim, kadınlar ve burçlar [Hedonic consumption, women and horoscopes]. Int. Journal of Management Economics and Business, 13(1), 117-135.

Özkan, B., Benli, T., \& Kizgin, Y. (2013). Is there any impact of horoscopes on luxury consumption trends. Business Management Dynamics, 3(2), 69-83.

Özkan, B., Efe, A., \& Çakmak, A. Ç. (2017). Müşterilerin bilişsel, hedonik, sosyal ve etik açıdan deneyimsel değer algılamalarının karşılaştırılması: GRATİS örneği [Comparison of customer perceptions of cognitive, hedonic, social and ethical values: Example of GRATIS]. Itobiad: Journal of the Human \& Social Science Researches, 6(5), 2323-2350. 
Sarıtaş, E., \& Haşıloğlu, S. B. (2015). Çalışan kadınların özel alışveriş sitelerinden satın alımlarının hedonik amaçlı tüketim açısından incelenmesi [An investigation in terms of hedonic consumption of working women's purchasing from private shopping site]. Journal of Internet Applications and Management, 6(1), 53-62.

Tifferet, S., \& Herstein, R. (2012). Gender differences in brand commitment, impulse buying, and hedonic consumption. Journal of Product \& Brand Management, 21(3), 176-182.

Uslu Divanoğlu, S., \& Uslu, T. (2019). Astrolojinin tüketici davranışları üzerindeki etkisinin belirlenmesi [Determination the effect of astrology on consumer behaviors]. Firat University Journal of International Social Sciences, 29(1), 299-321.

Ünal, S., \& Ceylan, C. (2008). Tüketicileri hedonik alışverişe yönelten nedenler: İstanbul ve Erzurum illerinde karşılaştırmalı bir araştırma. Atatürk Üniversitesi İktisadi ve İdari Bilimler Dergisi, 22(2), 265-283. 